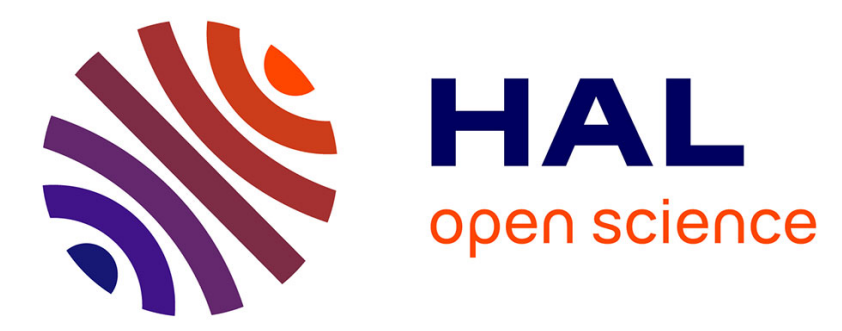

\title{
Effect of Annealing Temperature on Magnetic After-Effect in FeCuNbSiB Alloys
}

W. Ciurzynska, C. Gomez-Polo, J. Arcas, A. Hernando, J. Perez-Landazabal, J. Zbroszczyk

\section{- To cite this version:}

W. Ciurzynska, C. Gomez-Polo, J. Arcas, A. Hernando, J. Perez-Landazabal, et al.. Effect of Annealing Temperature on Magnetic After-Effect in FeCuNbSiB Alloys. Journal de Physique IV Proceedings, 1996, 06 (C8), pp.C8-549-C8-552. 10.1051/jp4:19968120 • jpa-00254551

\section{HAL Id: jpa-00254551 https://hal.science/jpa-00254551}

Submitted on 1 Jan 1996

HAL is a multi-disciplinary open access archive for the deposit and dissemination of scientific research documents, whether they are published or not. The documents may come from teaching and research institutions in France or abroad, or from public or private research centers.
L'archive ouverte pluridisciplinaire HAL, est destinée au dépôt et à la diffusion de documents scientifiques de niveau recherche, publiés ou non, émanant des établissements d'enseignement et de recherche français ou étrangers, des laboratoires publics ou privés. 


\title{
Effect of Annealing Temperature on Magnetic After-Effect in FeCuNbSiB Alloys
}

W.H. Ciurzynska, C. Gomez-Polo*, J. Arcas**, A. Hernando**, J.I. Perez-Landazabal* and

J. Zbroszczyk

Institute of Physics, Technical University of Czestochowa, Armii Krajowej 19, 42-200 Czestochowa,

Poland

*Departamento de Fisica, Universidad Publica de Navarra, Pamplona, Spain

** Instituto de Magnetismo Aplicado and Instituto de Ciencia de Materiales, Madrid, Spain

\begin{abstract}
The microstructure and magnetic properties i.e. the initial permeability, magnetic after-effect and coercivity for the as-quenched and annealed at different temperatures $\mathrm{Fe}_{73.5} \mathrm{Cu}_{1} \mathrm{Nb}_{3} \mathrm{Si}_{13.5} \mathrm{~B}_{9}$ samples are studied. After annealing the samples at $573 \mathrm{~K}$ for $1 \mathrm{~h}$ the decrease of the initial permeability and increase of the disaccommodation amplitude are observed. These are connected with a local anisotropy induced during this treatment. The increase of the annealing temperature causes the improvement of soft magnetic properties. However, after annealing the toroidal samples at $723 \mathrm{~K}$ for $1 \mathrm{~h}$ a magnetic hardening is observed. It seems to be connected with the appearance of $\alpha$ Fe-Si nuclei and clusters enriched in $\mathrm{Cu}$. Moreover, it was stated that the cooling conditions of the samples influence also their magnetic properties. Therefore, the values of coercivity obtained for annealed strips in comparison with corresponding results of $\mu$ ' obtained for toroids are shifted towards higher temperature by $50 \mathrm{~K}$.
\end{abstract}

\section{INTRODUCTION}

Nanocrystalline $\mathrm{Fe}_{73.5} \mathrm{Cu}_{1} \mathrm{Nb}_{3} \mathrm{Si}_{13.5} \mathrm{~B}_{9}$ alloys are prepared by controlled crystallization of initially amorphous ribbons. The best annealing conditions (typically $823 \mathrm{~K}$ for $1 \mathrm{~h}$ ) allow to obtain nanocrystalline alloys consisted of the $\alpha \mathrm{Fe}-\mathrm{Si}$ fine grains of about $10-20 \mathrm{~nm}$ in size randomly distributed in an amorphous matrix. This ultra-fine grain structure is achieved by combined addition of $\mathrm{Cu}$ and $\mathrm{Nb}$ [1]. This material exhibits excellent soft magnetic properties due to averaging the magnetocrystalline anisotropy and very low saturation magnetostriction [2].

The aim of this paper is to study the magnetic properties, i.e. initial relative permeability, its disaccommodation, woercivity and microstructure of the $\mathrm{Fe}_{73.5} \mathrm{Cu}_{1} \mathrm{Nb}_{3} \mathrm{Si}_{13.5} \mathrm{~B}$, alloy in the as-quenched state and after annealing in the temperature range from 573 to $873 \mathrm{~K}$ for $1 \mathrm{~h}$.

\section{EXPERIMENTAL PROCEDURE}

The ribbons of the $\mathrm{Fe}_{73.5} \mathrm{Cu}_{1} \mathrm{Nb}_{3} \mathrm{Si}_{13.5} \mathrm{~B}_{9}$ alloy were about $20 \mu \mathrm{m}$ thick and $2 \mathrm{~mm}$ wide. The initial permeability was measured for toroidal samples of $2 \mathrm{~cm}$ diameter using a completely automated set-up at room and nitrogen temperature. From these results the disaccommodation was calculated according to:

$$
\Delta(1 / \chi)=1 / \chi_{2}-1 / \chi_{1}=f(T)
$$

where $1 / \chi_{1}$ and $1 / \chi_{2}$ are reciprocal magnetic susceptibilities at times $t_{1}=2 \mathrm{~s}$ and $t_{2}=120 \mathrm{~s}$ after demagnetization, respectively. The amplitude and frequency of the magnetizing field were equal to 0.24 $\mathrm{A} / \mathrm{m}$ and $2 \mathrm{kHz}$, respectively. 
The coercivity was measured for the strips $10 \mathrm{~cm}$ long by an automated induction method. The microstructure of the samples was investigated by $\mathrm{X}$-ray diffractometry and differentional scanning calorimetry.

The investigations were carried out for the samples in the as-quenched state and after annealing the toroidal samples and strips for $1 \mathrm{~h}$ at the temperatures: $573,623,673,723,748,773,798,823$ and $848 \mathrm{~K}$.

\section{RESULTS}

The evolution of $\mathrm{X}$-ray diffraction patterns with annealing temperature (T) is plotted in Fig. 1. The samples in the as-cast state and after annealings below $750 \mathrm{~K}$ are characterized by the typical amorphous halo. Annealing temperature higher than $773 \mathrm{~K}$ gives rise to the precipitation of a randomly textured $\alpha \mathrm{Fe}-$ Si phase with mean grain diameter, obtained through Scherrer formula, around $12 \mathrm{~nm}$.



Figure 1: X-ray diffraction patterns obtained for the as-cast (curve 1) and annealed for $1 \mathrm{~h}$ at the temperatures: 573,623 , $673,723,748,773,798,823$ and $848 \mathrm{~K}$ samples (curves $2-10$, respectively)

The results of the magnetic properties measurements are shown in Figs 2-4. Experimental points in these figures are linked to show the tendency of the magnetic properties changes.

Fig, 2 shows the relative permeability $\mu^{2}=\mu / \mu_{0}$ (where $\mu$ is the permeability measured at $H_{m}=0.24$ $\mathrm{A} / \mathrm{m}$ and $\mathrm{t}_{1}=2 \mathrm{sec}$ after demagnetization and $\mu_{0}$ is the vacuum permeability) and the amplitude of disaccommodation $\Delta(1 / \chi)=f(T)$ for as-quenched and annealed samples obtained during measurements at room and nitrogen temperatures. A slight decrease of the permeability after annealing the sample at $573 \mathrm{~K}$ for $1 \mathrm{~h}$ can be detected; then it increases with annealing temperature $(\mathrm{T})$ up to $848 \mathrm{~K}$ except the samples annealed at $723 \mathrm{~K}$ where $\mu^{\prime}$ drops to about 400 . The dependence of the relative permeability on annealing temperature obtained at nitrogen temperature is similar to the previous one (Fig.2a).

The disaccommodation reaches the maximum after annealing the sample at $573 \mathrm{~K}$; the next smaller maximum is observed after annealing at $723 \mathrm{~K}$ for $1 \mathrm{~h}$. After annealing the sample above $773 \mathrm{~K}$ the disaccommodation drops almost to zero. Similar behaviour exhibits the disaccommodation during measurements at nitrogen temperature (Fig.2b).

In Fig. 3 the coercive field $\left(\mathrm{H}_{c}\right)$ versus annealing temperature is shown. The coercivity slightly increases after annealing the samples at $623 \mathrm{~K}$ and subsequently shows the distinct maximum after 
annealing the samples at $\mathrm{T}=773 \mathrm{~K}$. The further increase of annealing temperature leads to the drop of $\mathrm{H}_{\mathrm{c}}$.

\section{DISCUSSION}

The magnetic properties observed for the $\mathrm{Fe}_{73.5} \mathrm{Cu}_{1} \mathrm{Nb}_{3} \mathrm{Si}_{13.5} \mathrm{~B}_{9}$ alloy are highly influenced by their microstructure which depends on annealing conditions. During annealing the amorphous samples of these



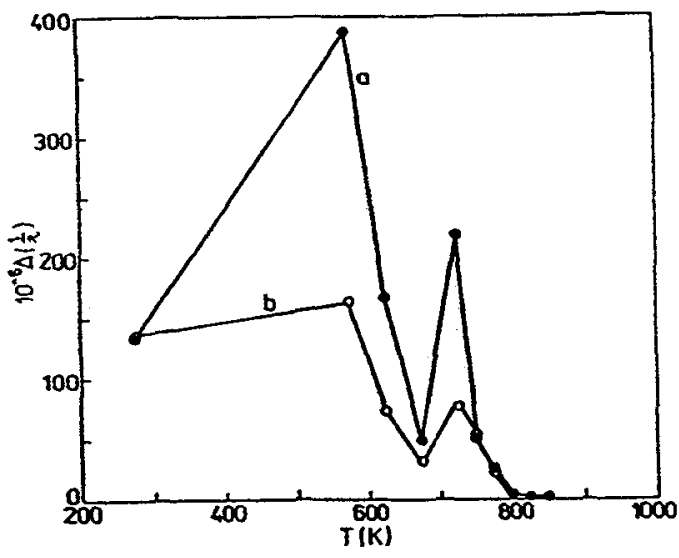

b

Figure 2: The dependence of $\mu^{\prime}=\mu^{\prime} \mu_{0}$ (a) and $\Delta(1 / \chi)$ (b) on annealing temperature (T) for as-cast and annealed samples obtained at room (curve a) and nitrogen temperatures (curve b), respectively.

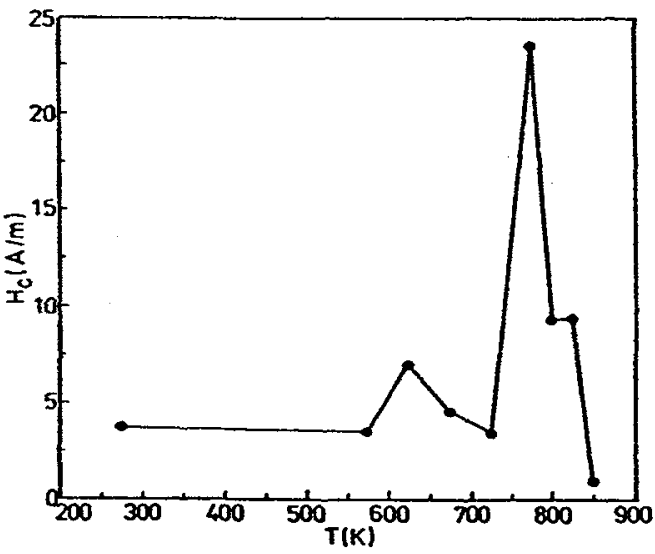

Figure 3: The coercive field $\left(\mathrm{H}_{c}\right)$ versus annealing temperature $(\mathrm{T})$ obtained for the $\mathrm{Fe}_{73.5} \mathrm{Cu}_{1} \mathrm{Nb}_{3} \mathrm{Si}_{13.5} \mathrm{~B}_{9}$ alloy.

alloys below crystallization temperature, mainly two effects occur: inducing of the local magnetic anisotropy and annealing out of free volumes which caused the stress-relief. When the sample is annealed at temperature $\mathrm{T}<\mathrm{T}_{\mathrm{c}}\left(\mathrm{T}_{\mathrm{c}}\right.$ - Curie temperature) the domain structure exists and the internal field within each domain can induce the local anisotropy. The second effect is dominant during annealing the samples at temperatures $T \geq T_{c}$. 
The samples in the as-quenched state exhibit rather poor soft magnetic properties, i.e. low relative permeability (about 400) and high coercivity (about $4 \mathrm{~A} / \mathrm{m}$ ) due to internal stresses frozen-in during the ribbon's preparation. After annealing the toroidal samples at $573 \mathrm{~K}$ and strips at $623 \mathrm{~K}$ for $1 \mathrm{~h}$ the decrease of permeability and increase of coercivity, respectively, is observed (Figs 2 and 3). This behaviour may be explained by local induced magnetic anisotropy which leads to domain wall stabilization. According to results obtained by $P$.Allia and $F$. Vinai [4], the after-effect of magnetic induction at $B=0$ may be described by

$$
\left(\frac{\Delta \mathrm{B}}{\mathrm{B}}\right)_{\mathrm{B}=0}=\frac{5}{8} \frac{\pi^{2} \mathrm{~K}_{\mathrm{u}} \mu_{0} \mathrm{~L}}{\mathrm{M}_{\mathrm{s}} \mathrm{A}}
$$

where L,A.M $\mathrm{M}_{\mathrm{s}}$ are the distance between walls, mean wall thickness and saturation magnetization, respectively. Thus the increase in induced anisotropy $\left(\mathrm{K}_{\mathrm{u}}\right)$ should increase the disaccommodation amplitude after annealing the samples at $573 \mathrm{~K}$, which is experimentally observed (Fig.2b). Annealing at higher temperatures leads to the increase of the permeability and decrease of the disaccommodation amplitude and coercivity. This is caused by annealing out of free volumes and stress relief of the samples. However, a magnetic hardening is observed after annealing the toroidal samples at $723 \mathrm{~K}$ and strips at 773 $\mathrm{K}$ for $1 \mathrm{~h}$ (Figs 2 and 3).. It seems to be connected with the appearance of $\alpha \mathrm{Fe}$-Si nuclei and clusters enriched in $\mathrm{Cu}$ as X-ray diffraction and differential scanning calorimetry show [4-6]. The further enhancement of annealing temperature up to $848 \mathrm{~K}$ leads to the increase of $\mu$ and decrease of $\mathrm{H}_{\mathrm{c}}$ due to stress-relief of samples and more effective averaging of magnetocrystalline anisotropy caused by occurrence of $\alpha \mathrm{Fe}-\mathrm{Si}$ fine grains. As for disaccommodation, its amplitude decreases despite the volume fraction of the crystalline phase increases and is connected with annealing out more and more free volumes in the amorphous matrix [7]. This result indicate that the processes occurring in the amorphous matrix are the main source of the magnetic after-effect in nanocrystalline alloys $[8,9]$.

It is worth noticing that during measurements at nitrogen temperature $(77 \mathrm{~K})$ a decrease of $\mu$ and disaccommodation amplitude is observed, which is connected with freezing spins in some regions of the samples [10].

\section{CONCLUSIONS}

1. After annealing the toroidal samples of the $\mathrm{Fe}_{73.5} \mathrm{Cu}_{1} \mathrm{Nb}_{3} \mathrm{Si}_{13.5} \mathrm{~B}_{9}$ alloy at $573 \mathrm{~K}$ and strips at $623 \mathrm{~K}$ for 1 $h$ the deterioration of the soft magnetic properties i.e. the decrease of the initial permeability and increase of coercivity and disaccommodation amplitude are observed.

2. The magnetic hardening occurs after heat treatment the toroidal samples and strips, respectively, at 723 and $773 \mathrm{~K}$ for $1 \mathrm{~h}$.

3. The appearance of the $\alpha \mathrm{Fe}-\mathrm{Si}$ grains leads to the increase of the magnetic permeability and decrease of the coercivity and disaccommodation amplitude.

\section{References}

[1] Yoshizawa Y., Yamauchi K., Mater. Trans. J.I.M. 31(1990) 307

[2] Herzer G., IEEE Trans. Mag. 26 (1990) 1397..

[3] Allia P., Vinai F., IEEE Trans.Magn. MAG-17 (1981)1481

[4] Marin P., Olofinjana A.O., Vazquez M., Davies H.A., IEEE Trans. Mag. MAG-30 (1994) 4794

[5] Chen W-Z., Li Z-H., Zhang G-X, J.Magn.Magn.Mater. 146 (1995) 354

[6] Gomez-Polo C., Holzer D., Multigner M., Navarro E., Agudo P., Hernando A., Vazguez M., Sassik H., Grossinger R., Phys. Rev. B 53 (1996) 3392

[7] Kronmüller H., J.Magn.Magn,Mater. 41 (1984) 366

[8] Zbroszczyk J., phys.stat.sol. (a) 153 (1996) 507

[9] Zbroszczyk J., W.Ciurzynska, to be published

[10] Zbroszczyk J., phys.stat.sol. (a) 142 (1994) 207 